\title{
Runoff-driven export of particulate organic carbon from soil in temperate forested uplands
}

Joanne C. Smith ${ }^{1}$, Albert Galy ${ }^{1}$, Niels Hovius ${ }^{1,2}$, Andrew M. Tye ${ }^{3}$, Jens M. Turowski ${ }^{4}$, Patrick Schleppi ${ }^{4}$

${ }^{1}$ Department of Earth Sciences, University of Cambridge, Cambridge, UK

${ }^{2}$ Present address: German Research Centre for Geosciences GFZ, Potsdam, Germany

${ }^{3}$ British Geological Survey, Keyworth, Nottingham, UK

${ }^{4}$ Swiss Federal Research Institute WSL, Birmensdorf, Switzerland

Corresponding author:

J. C. Smith

Department of Earth Sciences, University of Cambridge, Downing Street, Cambridge CB2 3EQ, UK

jcs74@cam.ac.uk

Phone: $+44(0) 1223333455$

Fax (department reception): +44 (0)1223 333450 


\section{Abstract}

We characterise the sources, pathways and export fluxes of particulate organic carbon (POC) in a headwater catchment in the Swiss Alps, where suspended sediment has a mean organic carbon concentration of $1.45 \% \pm 0.06$. By chemically fingerprinting this carbon and its potential sources using carbon and nitrogen elemental and isotopic compositions, we show that it derives from binary mixing between bedrock and modern biomass with a soil-like composition. The hillslope and channel are strongly coupled, allowing runoff to deliver recent organic carbon directly to the stream beyond a moderate discharge threshold. At higher flows, more biomass is mobilized and the fraction of modern carbon in the suspended load reaches 0.70 , increased from 0.30 during background conditions. Significant amounts of non-fossil organic carbon are thus transferred from the hillslope without the need for extreme events such as landsliding. Precipitation is key: as soon as the rain stops, biomass supply ceases and fossil carbon again dominates. We use rating curves modeled using samples from five storm events integrated over 29-year discharge records to calculate long-term export fluxes of total POC and non-fossil POC from the catchment of $23.3 \pm 5.8$ and $14.0 \pm 4.4$ tonnes $\mathrm{km}^{-2} \mathrm{yr}^{-1}$ respectively. These yields are comparable to those from active mountain belts, yet the processes responsible are much more widely applicable. Such settings have the potential to play a significant role in the global drawdown of carbon dioxide via riverine biomass erosion, and their contribution to the global flux of POC to the ocean may be more important than previously thought. 


\section{Keywords}

Organic carbon, stable isotope geochemistry, carbon export, mountain rivers, runoff processes 


\section{Introduction ${ }^{1}$}

3 Export and deep marine burial of carbon from plants and soils, recently fixed from the

4 atmosphere by photosynthesis, transfers carbon from the atmosphere into geological

5 storage (e.g. Berner, 1982; France-Lanord and Derry, 1997). Previous work on

6 carbon export from catchments has focused on active mountain belts because of their

7 importance in the physical erosion budget (Milliman and Syvitski, 1992). For

8 example, recent studies (Carey et al., 2005; Hilton et al., 2008a, 2008b; Lyons et al.,

9 2002) suggest that storm-driven erosion of terrestrial biomass can effectively

10 sequester carbon in tectonically and climatically extreme regimes, such as the active

11 mountain belts of Taiwan and New Zealand. Deep-seated landslides and gully

12 erosion are important in mobilising particulate organic carbon (POC) in extreme

13 events in these environments (Hilton et al., 2008a; West et al., 2011). This POC

14 consists of both modern POC from biomass and fossil POC from sedimentary

15 bedrock. However, there are also indications that erosion processes associated with

16 less intense runoff, driven directly by precipitation, may also be important,

17 particularly in shifting the balance of POC carried in the suspended load towards non-

18 fossil sources (Gomez et al., 2010; Hilton et al., 2012a, 2008b). While deep

19 landslides and gully erosion mobilize bedrock as well as POC, runoff erosion via

\footnotetext{
${ }^{1}$ Abbreviations used throughout the article:

POC: particulate organic carbon

tPOC: total particulate organic carbon

fPOC: fossil particulate organic carbon

nfPOC: non-fossil particulate organic carbon

$\mathrm{C}_{\text {org }}$ : organic carbon concentration

SS: suspended sediment

SSC: suspended sediment concentration

TSL: total suspended load

$F_{n f}$ : modeled fraction of non-fossil organic carbon

$\mathrm{F}_{\text {mod }}$ : fraction of non-fossil organic carbon obtained from radiocarbon measurements

Qe: effective discharge
} 
overland flow removes only the surface layer of soil (Horton, 1945). If such processes are significant, the harvest of non-fossil POC stored in plants and soils could happen anywhere that there is enough rain on vegetated hillslopes to generate overland flow or shallow landslides.

Evidence for terrestrial POC export in temperate settings unaffected by rapid uplift and tropical storms exists in marine sediments (Gordon and Goñi, 2003; Prahl et al., 1994) and in inputs to the ocean (Hatten et al., 2012), but there is still insufficient understanding of the processes which mobilize POC in the headwater source areas of these deposits. Here, we investigate POC sources and initial pathways under changing hydrologic conditions in a temperate, partly forested headwater catchment in the Swiss Prealps, where the runoff effect is not normally masked by deep-seated landsliding. We find strong evidence for runoff-driven transfer of significant amounts of modern soil-derived biomass during moderate hydrologic conditions, with the proportion of modern carbon in the suspended load increasing with discharge.

\section{Study Site}

\section{The Erlenbach is a first order tributary of the Alp River, located $40 \mathrm{~km}$ south of} Zurich near the town of Einsiedeln. It has a small catchment area $\left(0.74 \mathrm{~km}^{3}\right)$, elevation 1110 to $1655 \mathrm{~m}$ above sea level and average slope of 20\% (Hagedorn et al., 2000). The mean annual air temperature is $6^{\circ} \mathrm{C}$ and mean annual precipitation is $2300 \mathrm{~mm}$ (Hagedorn et al., 2001), $800 \mathrm{~mm}$ of this falling as snow in winter (Schleppi et al., 2005). The largest precipitation events occur as convective rainfall during the summer. In common with other small mountain river systems (Wheatcroft et al., 
2010), discharge rises quickly during storms and is highly episodic in response to rainfall (Schleppi et al., 2006).

The catchment is developed on pelitic turbidites of the Eocene Wägital-Flysch Formation (Winkler et al., 1985). Recent glacial till overlies these rocks, particularly at lower elevations with a cover of up to several metres thick on the lower left bank. Both bedrock and drift are fine-grained, clay-rich and impermeable, resulting in water-saturated gleysols. Creep landslides are common, particularly in the lower reaches where steep channel sides cut into active complexes developed mainly in the till. These incrementally deliver substantial amounts of sediment to the stream channel during winter, which is removed by summer storms (Schuerch et al., 2006). The Erlenbach lacks a well-developed riparian zone and has a step-pool morphology with both logs and boulders forming the steps (Turowski et al., 2009). The catchment is $40 \%$ forest and $60 \%$ wetland and alpine meadow (Turowski et al., 2009). The main tree species are Norway Spruce (Picea abies) and European Silver Fir (Abies alba), with some green Alder (Alnus viridis) (Schleppi et al., 1999).

The Erlenbach is an experimental catchment of the Swiss Federal Institute for Forest, Snow and Landscape Research (WSL) (Hegg et al., 2006). Over the time period 1983-2011 inclusive, discharge (Q) recorded at 10-minute intervals ranged from 0 to $119461 \mathrm{~s}^{-1}$ with an average $\left(\mathrm{Q}_{\text {mean }}\right)$ of $38.61 \mathrm{~s}^{-1}$. In this study, we report discharges relative to this value (as $\mathrm{Q} / \mathrm{Q}_{\text {mean }}$ ), as well as absolute values, to allow comparison to other catchments. Over the monitoring period, flow was less than or equal to $\mathrm{Q}_{\text {mean }}$ for $77 \%$ of the time, with such discharges accounting for about $1 \%$ of suspended sediment transport. Less than $1 \%$ of discharges were above the threshold at which 
substantial bedload transport starts, which corresponds to $\mathrm{Q} / \mathrm{Q}_{\text {mean }} \sim 13$ (Turowski et al., 2011). The catchment is also a site for the NITREX project (NITRogen saturation EXperiments) (Wright and Rasmussen, 1998), and has three $<1$ ha sub-plots equipped with V-notch weirs in forest, forest with experimental nitrogen addition, and meadow (Schleppi et al., 1998).

\section{Methods}

POC in riverine suspended sediment is a mixture of carbon from two or more end member sources (Blair et al., 2003; Hilton et al., 2008a, 2008b; Komada et al., 2004; Leithold et al., 2006). It is particularly important to distinguish between carbon from fossil and non-fossil sources, because re-burial of fossil carbon has no effect on contemporary $\mathrm{CO}_{2}$ drawdown, while burial of non-fossil carbon bypasses the usual rapid oxidation pathway and sequesters carbon (Berner, 1982). Mixing relationships can be primarily elucidated in $\mathrm{N} / \mathrm{C}-\delta^{13} \mathrm{C}$ and $\mathrm{C} / \mathrm{N}-\delta^{15} \mathrm{~N}$ space (e.g. Hilton et al., 2010), while ${ }^{14} \mathrm{C}$ provides an additional constraint on the input of fossil carbon (e.g. Blair et al., 2003; Hilton et al., 2008b; Komada et al., 2005).

\subsection{Sample Collection}

Instantaneous suspended sediment samples were collected direct from the stream at the upper gauging station in $100 \mathrm{ml}$ plastic bottles, every few minutes during five storm events in July 2010. The largest of these (12 July) had a return period of about one year and a peak discharge of $22901 \mathrm{~s}^{-1}$, corresponding to a $\mathrm{Q} / \mathrm{Q}_{\text {mean }}$ of $\sim 59$. The remaining four events took place within 10 days and covered a range of peak 
95 discharges from 300 to $15801 \mathrm{~s}^{-1}$ [Table 1]. With the exception of the 12 July event, 96 the storms were characterised by intermittent rain. The hydrographs for three of the events are shown in Figure 1. After collection, each turbid sample was passed through a $0.2 \mu \mathrm{m}$ nylon filter within two weeks (mostly within three days), following interim storage at $5{ }^{\circ} \mathrm{C}$. The filters with sediment were stored in glass petri dishes at -

$100 \quad 18^{\circ} \mathrm{C}$ before lyophilization.

101

102110 samples from potential sources for the riverine suspended sediment, including

103 bedrock, surface soil, deeper soil profiles, foliage, wood, bedload and material from

104 landslides and banks adjoining the channel, were collected between October 2009 and

105 August 2010. All samples were stored in sealed plastic bags and oven-dried in

106 covered foil dishes at $<80^{\circ} \mathrm{C}$ as soon as possible (1-12 days) after collection.

107

108 Surface soil and foliage were collected in transects across the catchment at a range of

109 elevations, covering all major geomorphologic and ecologic conditions. At each

110 locality, samples as representative as possible of the immediate surroundings were

111 taken. Surface soil (a combination of O and A layers) was collected from the top $\sim 10$

$112 \mathrm{~cm}$ with a clean trowel, after removal of overlying vegetation. Although the timing of

113 collection could potentially affect the isotopic composition of soil samples because

114 more decomposed litter could be enriched in ${ }^{13} \mathrm{C}$ and ${ }^{15} \mathrm{~N}$ (e.g. Dijkstra et al., 2008),

115 the collection method and subsequent processing result in samples homogenised over

116 a long enough period to negate any seasonal differences. Foliage included multiple

117 samples, comprising needles, leaves and twigs from all sides, of the three main tree

118 types and representative understory. Samples of woody debris embedded in

119 landslides and the channel bed were also collected across the catchment. Throughout 
this study, 'foliage' and 'wood' are used as convenient terms for different types of

121 standing biomass, and include all associated microbial organisms.

123 Two vertical profiles were taken through landslides (down to $80 \mathrm{~cm}$ and $170 \mathrm{~cm}$ ), and

124 two through stable hillslopes (to $60 \mathrm{~cm}$ and $160 \mathrm{~cm}$ ); these were sampled at $10-60 \mathrm{~cm}$

125 intervals. In reporting the results, the uppermost soil samples from each stable

126 hillslope profile are treated as 'surface soils' and are excluded from the profile group

127 ('deep soils'). Soil is generally poorly developed on top of the landslides and so no

128 such distinction is made. 22 bedrock samples were obtained across the catchment

129 (from both hillslopes and stream bed). Bedload was collected along the full length of 130 the main channel.

132 Discharge-proportional compound samples of suspended sediment were collected

133 from the forest control and meadow sub-plots weekly (when there was enough runoff)

134 between August 2009 and August 2011. A representative subset of each of these was 135 analyzed to obtain an estimate of the hillslope input signal.

\subsection{Sample Preparation}

139 For source sediments, only the suspendable fraction $(<2 \mathrm{~mm})$, isolated through wet-

140 and dry-sieving, was subjected to further analysis. Suspended sediment occasionally

141 contained material $>2 \mathrm{~mm}$; these particles, mainly large organic material such as

142 spruce or fir needles, were excluded from chemical analysis, though their weight was

143 recorded and used in calculations of suspended sediment concentrations. Bedrock and 144 vegetation samples were analyzed in bulk. 
146 All samples were homogenized using either a ball mill grinder, a pestle and mortar

147 (for small samples) or a blade mill grinder (for vegetation). Bedrock samples were

148 first crushed using a jaw crusher to fragments $<5 \mathrm{~mm}$. Pulverized samples and blanks

149 were heated to $80^{\circ} \mathrm{C}$ with dilute $(1 \mathrm{M})$ hydrochloric acid for three hours to remove

150 carbonate, rinsed with de-ionized water and dried thoroughly (France-Lanord and

151 Derry, 1994; Galy et al., 2007a; Hilton et al., 2008a). Between 5 and 30\% of each

152 sample was lost through the carbonate removal process, with no apparent disparity

153 between different types of material. Most of this loss corresponds to carbonate

154 dissolution plus loss of particles on the vessels used in treatment (Galy et al., 2007a;

155 Hilton et al., 2008a; Brodie et al., 2011). This process unavoidably causes loss of a

156 labile fraction of organic $\mathrm{C}$, and the results reported here relate to the non-labile

157 fraction only. However, it is this more recalcitrant fraction that is most likely to be

158 ultimately buried in the ocean, and therefore of interest in this study. This procedure

159 was carried out on all samples (including vegetation), so that any isotopic

160 fractionation effects of the de-carbonation process (Brodie et al., 2011) are universally

161 applied and the results are internally consistent.

162

163 3.3 Analysis

164

165 Processed, powdered samples were combusted, and the resultant $\mathrm{N}_{2}$ and $\mathrm{CO}_{2}$

166 concentrations (reported in weight \%) and carbon and nitrogen isotopic compositions

$167\left(\delta^{13} \mathrm{C}\right.$ and $\delta^{15} \mathrm{~N}$, reported in \%o) were obtained using a flash Elemental Analyser

168 coupled to a continuous flow Nier-type mass spectrometer via a gas bench for gas

169 separation. All measurements were corrected for procedural blanks following 
170 published methods (Hilton et al., 2010; 2012b). Multiple aliquots of varying material

171 were analyzed; the average relative difference was $<<0.001 \%$ for $\mathrm{C}$ and $\mathrm{N}$, and

172 average standard deviation was $0.05 \%$ for $\delta^{13} \mathrm{C}$ and $0.3 \%$ for $\delta^{15} \mathrm{~N}$. To test for long-

173 term machine drift, 10 samples were analyzed a second time one year after the first

174 analysis. This set of repeats had an average relative difference of $0.06 \%$ for $\mathrm{C}$ and

$175 \quad 0.07 \%$ for $\mathrm{N}$, and average standard deviation of $0.05 \%$ for $\delta^{13} \mathrm{C}$ and $0.3 \%$ for $\delta^{15} \mathrm{~N}$.

176

$177{ }^{14} \mathrm{C}$ measurements on 14 graphitized samples were obtained by accelerator mass

178 spectrometry at the NERC Radiocarbon Laboratory in East Kilbride, UK. Reported

179 results comprise the proportion of ${ }^{14} \mathrm{C}$ atoms in each sample compared to that present

180 in the year $1950\left(\mathrm{~F}_{\bmod }\right), \Delta^{14} \mathrm{C}$ in \%o, and conventional radiocarbon age. The standard

181 IAEA-C5, subjected to the same carbonate-removal procedure as the samples,

182 returned ${ }^{14} \mathrm{C}$ to within $1 \sigma$ of the consensus value.

183

184 4. Results

185

4.1 Concentration and Composition of Organic Carbon in Source Materials

187

188 Composition data for riverine suspended sediment, hillslope runoff input and major

189 carbon stores within the catchment are summarised in Table 2 while the radiocarbon

190 data are shown separately in Table 3.

191

192 Bedrock has organic carbon concentrations $\left(\mathrm{C}_{\mathrm{org}}\right)$ ranging from $0.16-1.15 \%$, with a

193 mean of $0.54 \% \pm 0.11\left( \pm 2 \sigma_{\text {mean }}, \mathrm{n}=22\right), \mathrm{C} / \mathrm{N}$ of $7.81 \pm 1.7, \delta^{13} \mathrm{C}=-25.71 \%$ o \pm 0.36

194 and $\delta^{15} \mathrm{~N}=3.34 \% \pm 0.26$. Bedload, channel banks and landslide deposits have 
195 similarly low $\mathrm{C}_{\text {org }}$ (all means $<1 \%$ ), and are compositionally very similar to bedrock.

196 Modern sources, surface soil $(\mathrm{n}=17)$ and foliage $(\mathrm{n}=8)$, have significantly higher

$197 \mathrm{C}_{\text {org }}(16.5 \% \pm 6.3$ and $46.9 \% \pm 2.0$ respectively $)$. Both pools have high $\mathrm{C} / \mathrm{N}$ and are

198 depleted in heavy isotopes of $\mathrm{C}$ and $\mathrm{N}$, but do not overlap: surface soil has $\mathrm{C} / \mathrm{N}$ of

$19917.9 \pm 2.2, \delta^{13} \mathrm{C}$ of $-26.84 \% \pm \pm 0.48$ and $\delta^{15} \mathrm{~N}$ of $-1.33 \%$ \pm 0.76 , while foliage has $\mathrm{C} / \mathrm{N}$

200 of $55.5 \pm 17, \delta^{13} \mathrm{C}$ of $-28.30 \% \pm \pm 1.13$ and $\delta^{15} \mathrm{~N}$ of $-5.87 \%$ o \pm 1.67 . The ${ }^{14} \mathrm{C}$ results

201 from surface soils show that they are essentially modern; the one soil $\mathrm{F}_{\text {mod }}$ value of

202 less than 1 is explained by its close association with a landslide and lack of overhead

203 forest canopy. Woody debris (up to 4000 years old) have high $\mathrm{C}_{\text {org }}(49.1 \% \pm 1.8 ; \mathrm{n}=$

204 12), high $\mathrm{C} / \mathrm{N}(173 \pm 98)$, are depleted in ${ }^{15} \mathrm{~N}\left(\delta^{15} \mathrm{~N}=-3.99 \% \pm \pm 1.29\right)$, and enriched in

$205{ }^{13} \mathrm{C}\left(\delta^{13} \mathrm{C}=-25.25 \% \pm \pm 0.69\right)$, in contrast to modern vegetation.

207 Landslide complexes have homogeneous compositions throughout their depth, with

208 no systematic variations in $\mathrm{C}_{\mathrm{org}}, \mathrm{C} / \mathrm{N}, \delta^{13} \mathrm{C}$ or $\delta^{15} \mathrm{~N}$. In contrast, the soil profiles from

209 stable slopes show a significant decrease in $\mathrm{C}_{\text {org }}$ and $\mathrm{C} / \mathrm{N}$ (to levels comparable to the

210 landslides) at $\sim 40-60 \mathrm{~cm}$ depth, although there are no clear patterns in isotopic

211 composition. The landslide profiles sampled show very little incorporation of non-

212 fossil material, while the soil profiles (even without the uppermost samples) document

213 a transition from surface-like horizons to a more fossil-like layer at depth.

\subsection{Concentration of Organic Carbon in Riverine Suspended Sediment}

217 The observed range of $\mathrm{C}_{\text {org }}$ in riverine suspended sediment samples was $0.78-2.52 \%$,

218 with a mean of $1.45 \% \pm 0.06\left( \pm 2 \sigma_{\text {mean }}, \mathrm{n}=122\right)$. Within each event, there appears to

219 be no consistent pattern in $\mathrm{C}_{\text {org }}$ over the hydrograph [Figure 1]. However, when all 
data are considered together, there is a clear parabolic pattern in the variation of $\mathrm{C}_{\mathrm{org}}$

221 with both Q and suspended sediment concentration (SSC), with negligible difference

222 in $\mathrm{C}_{\text {org }}$ patterns between rising and falling limbs. The product of $\mathrm{Q}$ and SSC combines

223 both effects in the parameter 'total suspended load' (TSL, in $\mathrm{g} \mathrm{s}^{-1}$ ) [Figure 2]. At low

224 TSL, $\mathrm{C}_{\text {org }}$ is initially variable, then decreases with increasing TSL. Beyond a

225 threshold of $\sim 500 \mathrm{~g} \mathrm{~s}^{-1}$ (corresponding to Q/Qmean $\sim 10$ and $\mathrm{SSC} \sim 1600 \mathrm{mg} \mathrm{l}^{-1}$ ), $\mathrm{C}_{\text {org }}$

226 increases: this trend continues up to at least $\sim 40000 \mathrm{~g} \mathrm{~s}^{-1}\left(\mathrm{Q} / \mathrm{Q}_{\text {mean }} \sim 60\right)$. The

227 threshold is reached under moderate conditions, occurring several times per year, and

228 in four of the five events sampled. Because of this change in behaviour, we take

229 flows of $\mathrm{Q} / \mathrm{Q}_{\text {mean }}<10$ to represent background conditions, after Gomez et al. (2010).

\subsection{Composition of Organic Carbon in River and Runoff Suspended Sediment}

$233 \mathrm{C} / \mathrm{N}$ ranges from 6.9 to 13 , with a mean of $9.55 \pm 0.24\left( \pm 2 \sigma_{\text {mean }}, \mathrm{n}=122\right) ; \delta^{13} \mathrm{C}$ ranges 234 from -27.55 to $-24.25 \%$ with a mean of $-26.33 \%$ w \pm 0.08 ; and $\delta^{15} \mathrm{~N}$ ranges from 0.15 235 to $5.08 \%$ with a mean of $2.21 \%$ \pm 0.16 . There are compositional differences between 236 samples collected on the rising and falling limbs, and during rain and dry periods 237 [Table 2], with the former group having higher $\mathrm{C} / \mathrm{N}$ and lower $\delta^{13} \mathrm{C}$ and $\delta^{15} \mathrm{~N}$ in each 238 case. The mean $\mathrm{F}_{\text {mod }}$ for the six suspended sediment samples sent for $\Delta^{14} \mathrm{C}$ analysis 239 was $0.65 \pm 0.08\left( \pm 2 \sigma_{\text {mean }}, \mathrm{n}=6\right)$. In both $\mathrm{N} / \mathrm{C}-\delta^{13} \mathrm{C}$ and $\mathrm{C} / \mathrm{N}-\delta^{15} \mathrm{~N}$ compositional space 240 where mixing relationships are linear, POC in riverine suspended sediment samples 241 plots in a broadly linear range bounded approximately by bedrock and soil [Figure 3].

242 Suspended sediment samples with higher $\delta^{15} \mathrm{~N}$ than the bedrock range may indicate 243 that the stream is sampling bedrock compositions not exposed at the surface 244 elsewhere in the catchment. 
246 In contrast to most pools, the mean composition of carbon in the hillslope runoff 247 suspended sediment samples suggests different relationships in the N/C- $\delta{ }^{13} \mathrm{C}$ and $248 \mathrm{C} / \mathrm{N}-\delta^{15} \mathrm{~N}$ plots. In $\mathrm{N} / \mathrm{C}-\delta^{13} \mathrm{C}$ space, forest and meadow runoff samples have the same 249 composition within error, and lie at the low-N/C, low- $\delta^{13} \mathrm{C}$ end of the riverine 250 suspended sediment range. In $\mathrm{C} / \mathrm{N}-\delta^{15} \mathrm{~N}$ space, forest and meadow runoff are 251 compositionally distinct, and both lie outside the compositional range of riverine 252 suspended sediment [Figure 3]. Both sets of runoff samples have higher $\mathrm{C}_{\text {org }}$ values 253 than riverine suspended sediment, of $9.12 \% \pm 0.9\left( \pm 2 \sigma_{\text {mean }}, \mathrm{n}=38\right.$; forest $)$ and $15.9 \%$ $254 \pm 1.7\left( \pm 2 \sigma_{\text {mean }}, \mathrm{n}=10\right.$; meadow $)$.

\section{Discussion}

Both the compositional distribution and $\mathrm{F}_{\text {mod }}$ values of riverine suspended sediment are consistent with mixing between fossil and non-fossil end members. Although $\mathrm{C}_{\text {org }}$

260 in the suspended sediment is always higher than that of bedrock, indicating that there

261 is some non-fossil input at all times, this input becomes increasingly significant at

262 higher TSL and Q [Figure 4]. POC from samples collected at low TSL cover the 263 whole compositional range, but are strongly concentrated towards low $\mathrm{C} / \mathrm{N}$ and high $264 \delta^{13} \mathrm{C}$ and $\delta^{15} \mathrm{~N}$ (that is, a 'fossil' composition). During larger events, there is a bulk 265 shift away from the fossil towards the non-fossil end of the mixing line. 
Because the composition of the POC exported from the catchment plots in the space between several different carbon pools, careful definition of the end members is necessary. Although the 'fossil' chemical composition of bedload, landslides and channel banks suggests that these pools all derive from bedrock, we take bedrock 273 alone as the unequivocal fossil end member. Of the non-fossil carbon pools, surface 274 soil and foliage are closest to but not exactly on the mixing trend defined by bedrock 275 and the suspended sediment samples. Non-fossil material comes from a range of 276 sources, so we calculate a hypothetical non-fossil end member using $\mathrm{F}_{\text {mod }}$ and $\delta^{13} \mathrm{C}$ 277 following the procedure defined by Hilton et al. (2010). Briefly, the $\delta^{13} \mathrm{C}$ of the 278 individual non-fossil end member for each suspended sediment sample with known $279 \quad \mathrm{~F}_{\text {mod }}$ is calculated according to the mixing relationship

$$
\delta^{13} \mathrm{C}_{\text {sample }}=\mathrm{F}_{\text {mod }} \cdot \delta^{13} \mathrm{C}_{\mathrm{nf}}+\left(1-\mathrm{F}_{\mathrm{mod}}\right) \cdot \delta^{13} \mathrm{C}_{\mathrm{fos}}
$$

281 where $\delta^{13} \mathrm{C}_{\mathrm{nf}}$ and $\delta^{13} \mathrm{C}_{\text {fos }}$ are the $\delta^{13} \mathrm{C}$ values of a hypothetical non-fossil end member 282 and the average $\delta^{13} \mathrm{C}$ of bedrock samples respectively. The mean of the six calculated 283 values of $\delta^{13} \mathrm{C}_{\mathrm{nf}}$ is taken. We then use lines of best fit, calculated using only points 284 with $\mathrm{Q} / \mathrm{Q}_{\text {mean }}>10$, to find the corresponding $\mathrm{N} / \mathrm{C}, \mathrm{C} / \mathrm{N}$ and $\delta^{15} \mathrm{~N}$. Uncertainties of 285 twice the standard error on the mean of the initial $\delta^{13} \mathrm{C}$ value are propagated through 286 this calculation procedure. The resulting hypothetical end member [Figure 4] has $\mathrm{C} / \mathrm{N}$ 287 of $15.8 \pm 6.8, \delta^{13} \mathrm{C}$ of $-27.15 \% \pm \pm 0.53$ and $\delta^{15} \mathrm{~N}$ of $0.61 \% \pm \pm 1.40$. This is much more 288 similar to surface soil than foliage, suggesting that soil is heavily implicated in the 289 non-fossil POC input. It is also similar to the forest hillslope runoff signal in N/C$290 \quad \delta^{13} \mathrm{C}$ space, but the two have distinctly different $\delta^{15} \mathrm{~N}$ values.

292 The concentrations of fossil and non-fossil POC in milligrams per litre can be

293 obtained for each sample, and then used to determine independent relationships with 
discharge, if we know the proportion of organic carbon derived from non-fossil sources. Given the simple mixing exhibited by the system, it is possible to model this parameter for each suspended sediment sample, denoted $F_{\text {nf }}$ to distinguish it from $F_{\text {mod }}$ measured using ${ }^{14} \mathrm{C}$, using the mixing equation given above, the $\delta^{13} \mathrm{C}$ of the sample 298 and two end members (Hilton et al., 2010). We used bedrock and the hypothetical 299 non-fossil end member determined above. Owing to scatter in the system, calculated $300 \quad \mathrm{~F}_{\mathrm{nf}}$ values for $9 \%$ of the samples fell outside the possible range of $0-1.1$. For these, a 301 value of 0 or 1.1 was substituted as appropriate. On the samples sent for ${ }^{14} \mathrm{C}$ analysis, $302 \mathrm{~F}_{\mathrm{nf}}$ shows reasonable agreement with $\mathrm{F}_{\text {mod }}$, reproducing it to within 0.24 at the $95 \%$ 303 level.

\subsection{Long-Term Carbon Export Flux: Fossil and Non-Fossil Components}

It is important to consider not only the export of total carbon, but of fossil carbon and non-fossil carbon separately, because only non-fossil carbon burial has an effect on contemporary carbon dioxide drawdown (e.g. Berner, 1982; Blair and Aller, 2012). Because distinct pools of organic carbon behave differently, shown by the changing

311 composition of POC at different discharges, their long-term export should be

312 considered independently (Wheatcroft et al., 2010).

314 We used the calculated $\mathrm{F}_{\mathrm{nf}}$ values to construct rating curves describing the 315 relationships between discharge and load of four components: suspended sediment 316 (SS), total POC (tPOC), fossil POC (fPOC) and non-fossil POC (nfPOC). These are 317 all power laws of the form $a\left(\mathrm{Q} / \mathrm{Q}_{\text {mean }}\right)^{b}$ [Table 4; Figure 5]. Because of the threshold 318 switch to $\mathrm{POC}$ addition at $\mathrm{Q} / \mathrm{Q}_{\text {mean }}>10$, and the fact that flows above background 
conditions are disproportionately important in transporting sediment and POC, we would ideally only use samples at $\mathrm{Q} / \mathrm{Q}_{\text {mean }}>10$ to fit the rating curves. However, this

321 is mathematically unsatisfactory as it restricts the range of $Q / Q_{\text {mean }}$ to less than one

322 order of magnitude and results in large uncertainties on $a$ and $b$. We therefore use

323 relationships determined using the full sample set (three orders of magnitude in

$\left.324 \mathrm{Q} / \mathrm{Q}_{\text {mean }}\right)$, but check their geomorphological validity by comparing with those

325 determined using only samples with $\mathrm{Q} / \mathrm{Q}_{\text {mean }}>10$, finding in all cases that $a$ and $b$ are 326 well within error [Table 4].

328 The larger exponent for tPOC $(b=1.33)$ compared to SS $(b=1.19)$ means that 329 relatively more POC is exported at higher discharges than SS, in contrast to the 330 relationships seen in the Waipaoa River (New Zealand) and Alsea River (Oregon)

331 (Wheatcroft et al., 2010). The effect is even more pronounced for nfPOC $(b=1.45)$

332 than for tPOC. The exponent for fPOC $(b=1.08)$ is within error of that for SS, 333 reflecting their shared clastic origin. Differences in the rating curve exponents are 334 mirrored by those in effective discharge $\left(\mathrm{Q}_{\mathrm{e}}\right)$, the discharge that, on average, 335 transports the largest proportion of a given constituent load (Andrews, 1980; Nash, 336 1994; Wheatcroft et al., 2010). $\mathrm{Q}_{\mathrm{e}}$ is greatest for nfPOC (corresponding to Q/Q $\mathrm{Q}_{\text {mean }}$ of 337 13.4), and lowest for fPOC (5.6). Q for all four components [Table 4] corresponds to 338 similar flows (relative to $\mathrm{Q}_{\text {mean }}$ ) to many other small mountain rivers (Wheatcroft et 339 al., 2010).

341 Applying these rating relationships to the discharge record for the Erlenbach, we 342 modeled the export of the four components over the period 1983-2011 inclusive, with 343 full results shown in [Table 5]. The mean annual yields and export fluxes of each 
344 component were: $1220 \pm 232 \mathrm{t} \mathrm{yr}^{-1}$ and $1648 \pm 313 \mathrm{t} \mathrm{km}^{-2} \mathrm{yr}^{-1}(\mathrm{SS}) ; 17.3 \pm 4.3 \mathrm{t} \mathrm{yr}^{-1}$

345 and $23.3 \pm 5.8 \mathrm{t} \mathrm{km}^{-2} \mathrm{yr}^{-1}$ (tPOC); $7.4 \pm 1.2 \mathrm{t} \mathrm{yr}^{-1}$ and $10.1 \pm 1.6 \mathrm{t} \mathrm{km}^{-2} \mathrm{yr}^{-1}$ (fPOC);

346 and $10.4 \pm 3.2 \mathrm{t} \mathrm{yr}^{-1}$ and $14.0 \pm 4.4 \mathrm{t} \mathrm{km}^{-2} \mathrm{yr}^{-1}$ (nfPOC). These amounts of fossil and

347 non-fossil carbon exported were used to calculate a mean $\mathrm{F}_{\mathrm{nf}}$ value for each year, both

348 overall and at different discharges [Table 5]. According to the model, $61 \%$ of all the

349 organic carbon exported from the Erlenbach over this 29-year period came from non-

350 fossil sources (mean overall $\mathrm{F}_{\mathrm{nf}}=0.61 \pm 0.02$ ).

352 The yield of fPOC based on rating curve [Table 5] is within error of the 'expected'

353 mean annual yield of fossil carbon $\left(7.3 \pm 1.3 \mathrm{t} \mathrm{yr}^{-1}\right)$, reached by multiplying the

354 average $\mathrm{C}_{\text {org }}$ of the bedrock samples by suspended sediment yield. This suggests that

355 there is no significant remineralization of fossil organic carbon during bedrock

356 erosion and export from these headwaters, in common with findings from the French

357 Alpes-de-Haute-Provence (Graz et al., 2011), although oxidation may occur during

358 onward transport and floodplain storage (Bouchez et al., 2010).

360 The effect of the different rating curve exponents is illustrated by comparing the

361 proportional yields of each component at different discharges, with the largest flows

362 transporting a greater proportion of nfPOC than $\mathrm{TPOC}$, and a greater proportion of

363 tPOC than SS and fPOC. We define three discharge class boundaries, corresponding

364 to $\mathrm{Q} / \mathrm{Q}_{\text {mean }}=1,10$ and $60 . \mathrm{Q} / \mathrm{Q}_{\text {mean }}=10$ is the threshold above which $\mathrm{POC}$ is added,

365 while $\mathrm{Q} / \mathrm{Q}_{\text {mean }}=60$ is the approximate limit of discharges we have sampled. This

366 limit is only exceeded very rarely $\left(5.4 \times 10^{-5}\right.$ of the time), but can be exceeded

367 substantially: the largest discharge recorded in the 10-minute dataset during the

368 monitoring period was $119501 \mathrm{~s}^{-1}\left(\mathrm{Q} / \mathrm{Q}_{\text {mean }} \sim 309\right)$, on 25 July 1984. Our results show 
that the lowest discharge class (the state of the stream for over three quarters of the time) is insignificant in terms of both SS and POC export and POC would be dominated by fossil origin (modeled $\mathrm{F}_{\mathrm{nf}}=0.30$ ). Conversely, if the same rating curve applied above the upper limit, discharges of $\mathrm{Q} / \mathrm{Q}_{\text {mean }}>60$ would transport considerable quantities of sediment, POC and particularly nfPOC $(10,12$ and $13 \%$ of total transport respectively), despite occurring less than $0.01 \%$ of the time. Beyond $\mathrm{Q} / \mathrm{Q}_{\text {mean }}=60, \mathrm{~F}_{\mathrm{nf}}$ would be 0.76 if the same rating relationship applied. However, because of the lack of constraints on processes or suspended load at these flows, this assumption is not conservative; for example, if landslides are activated, there may be an increase in the proportion of fPOC. Instead, we assume a constant load of all four components for $\mathrm{Q} / \mathrm{Q}_{\text {mean }}>60$, giving $\mathrm{F}_{\mathrm{nf}}$ of 0.70 for this discharge range, and conservative estimate for the total yields.

\subsection{Sources and Pathways of Non-fossil Organic Carbon in the Erlenbach}

In order to draw more general conclusions from the detailed study of nfPOC export in the Erlenbach, the origins and harvesting mechanism of this nfPOC need to be better understood. When there is a small overall load, incidental, local mobilisation dominates and suspended sediment shows the natural variability of catchment composition and process [Figures 2 and 4]. Subsequent POC dilution to a minimum of $\sim 1 \%$ [Figure 2] must be due to an increased input of material with low $\mathrm{C}_{\text {org }}$, by a mechanism that does not require high-energy flows. This is likely due to higher discharge causing an increase in bed shear stress, which mobilizes fossil-derived material already in the channel. This lithic material (left by previous events, delivered to the channel by creep landslides, or exposed bedrock) contains small amounts of 
394 fossil $\mathrm{C}_{\text {org }}$ : bedrock, bedload, landslide and channel bank pools all have average $\mathrm{C}_{\text {org }}$ $395<1 \%$.

397 Beyond the $500 \mathrm{~g} \mathrm{~s}^{-1}$ threshold (at Q/Q $\mathrm{Q}_{\text {mean }} \sim 10$ ), material with a higher $\mathrm{C}_{\text {org }}$ than

398 bedrock or any of the groups derived from it must be added to the suspended load.

399 Addition of fossil organic carbon released from bedrock, either directly or via

400 landslides and channel banks, cannot explain the compositional trends observed in the

401 suspended load with increasing discharge [Figures 3 and 4]. Instead, the sourcing

402 mechanism must mobilize only surface soil, litter and vegetation, in a way that gives

403 the composition of the non-fossil end member calculated above. This strongly

404 suggests that surface runoff processes are responsible, but there is a compositional 405 discrepancy in $\delta^{15} \mathrm{~N}$ between runoff suspended sediment and the hypothetical end 406 member. However, the subplots (where the runoff suspended sediment samples were 407 collected) are situated towards the edge of the catchment, whereas runoff entering the 408 stream comes from lower, steeper hillslopes. Here, the bed stress is higher and runoff 409 may penetrate deeper via transient gullying (Horton, 1945), allowing overland flow to 410 pick up more soil and reducing $\delta^{15} \mathrm{~N}$ values to the hypothetical composition.

411 Considering these processes, hillslope activation driven by surface runoff can account

412 for the change in composition of river suspended sediment POC above background

413 flow, and so for the material added in this hydrological phase. This is supported by

414 end member mixing analysis using dissolved nutrient tracers in the Erlenbach

415 catchment which suggests that, at moderate summer storm peak discharges, over half

416 the runoff in the stream comes directly from precipitation (Hagedorn et al., 2000).

417 The $\mathrm{Q} / \mathrm{Q}_{\text {mean }}=10$ threshold, therefore, appears to reflect a critical shear stress at 418 which slope material is mobilised. 
420 The flood hydrographs [Figure 1] suggest that as soon as discharge has peaked,

421 hillslopes are deactivated and delivery of non-fossil organic carbon to the stream is

422 staunched, shown by decrease in $\mathrm{C} / \mathrm{N}$ and $\delta^{13} \mathrm{C}$. This reflects the differing

423 compositions of suspended sediment collected during the rising limb of the

424 hydrograph, when it is usually raining, and falling limb, when it is largely dry.

425 Similarly, the $F_{n f}$ value is significantly higher for samples collected during rainfall

$426\left(0.54 \pm 0.05 ; \pm 2 \sigma_{\text {mean }}, \mathrm{n}=85\right)$ and the rising $\operatorname{limb}(0.51 \pm 0.05 ; \mathrm{n}=72)$ than dry

427 periods $(0.25 \pm 0.06 ; \mathrm{n}=37)$ or the falling limb $(0.36 \pm 0.08 ; \mathrm{n}=50)$.

\subsection{Caveats}

431 So far we have only considered processes operating during moderate to large flows:

432 having only sampled up to $\mathrm{Q} / \mathrm{Q}_{\text {mean }} \sim 60$, we have no insight into the geomorphic

433 dynamic at very high flow rates. If extreme precipitation could trigger rapid

434 landslides, then the system may cross a threshold into a more 'active margin-like'

435 mode of behaviour, where mass wasting during storms causes progressive dilution of

436 modern organic carbon (Blair and Aller, 2012; Kao and Liu, 1996; Masiello and

437 Druffel, 2001).

439 The calculated $\mathrm{F}_{\mathrm{nf}}$ of POC exported from the catchment is systematically biased by

440 not including bedload, because bedload is closely related to bedrock [Figure 3] and

441 contains dominantly fossil carbon. This is particularly true in small catchments with

442 high sediment load like the Erlenbach, where bedload is relatively more important

443 than in large mountain rivers (Rickenmann et al., 2012). We chose to exclude 
444 bedload in order to enable comparison with other sites, since only suspended load data

445 are available at most locations. However, because bedload transport is constrained to 446 some extent in the Erlenbach, we briefly discuss the implications. The total sediment 447 volume accumulated in the retention basin between August 1982 and October 2012 448 was $17730 \mathrm{~m}^{3}$, including pore space and suspendable fines. Using a bulk density of $4491750 \mathrm{~kg} \mathrm{~m}^{-3}$ (Rickenmann and McArdell, 2007), and assuming that $75-80 \%$ of the 450 material is larger than $2 \mathrm{~mm}$, this gives $\sim 800$ tonnes per year. Using the bedrock $\mathrm{C}_{\text {org }}$ 451 of $0.54 \%$, this equates to an additional $\sim 4$ tonnes of organic carbon per year. An 452 alternative estimate, assuming that bedload volume is approximately equal to 453 suspended load volume in the Erlenbach (Turowski et al., 2010), gives an additional $454 \sim 7$ tonnes of organic carbon per year. These figures suggest that, if bedload as well as 455 suspended load is considered, the overall $\mathrm{F}_{\mathrm{nf}}$ would decrease from 0.6 [Table 5] to 456 between 0.4 and 0.5 . A further consideration is the possibility that non-fossil carbon 457 in the form of coarse woody debris is transported in the bedload, meaning that total 458 nfPOC export is also underestimated by our analysis. However, more work is needed 459 to quantify this.

461 Additional biases may result from the fact that our rating curves and flux estimates are 462 based on samples collected during the summer only and so take no account of 463 possible seasonal changes in the relationships between discharge and tPOC, fPOC and 464 nfPOC concentrations. It is likely that significantly different processes to those we 465 have constrained occur only during the winter and early spring, when there is snow on 466 the ground or melting. The last panel in Figure 1 shows that, although discharge is 467 highest during snow melt in April-May, suspended sediment concentrations are 468 relatively low throughout winter and spring. Multiplying mean discharge by mean 
SSC gives mean total suspended load values of $\sim 3 \mathrm{~g} \mathrm{~s}^{-1}$ for winter/spring (December-

470 May) and $\sim 15 \mathrm{~g} \mathrm{~s}^{-1}$ for summer/autumn (June-November). Thus, the mass of material 471 exported under the conditions we have constrained is approximately five times greater 472 than that exported at other times. Even if somewhat different processes were shown 473 to operate in winter and taken into account, the long-term fluxes would not change 474 substantially and our conclusions would be unaffected.

\subsection{Global Significance of POC Flux and Processes Observed in the Erlenbach}

478 The rate of export of non-fossil POC from the Erlenbach $\left(14.0 \pm 4.4\right.$ tonnes $\left.\mathrm{km}^{-2} \mathrm{yr}^{-1}\right)$ 479 is broadly comparable to yields of non-fossil POC reported from Taiwan $(21 \pm 10$ 480 tonnes $\left.\mathrm{km}^{-2} \mathrm{yr}^{-1}\right)$ (Hilton et al., 2012a) and New Zealand ( 39 tonnes $\left.\mathrm{km}^{-2} \mathrm{yr}^{-1}\right)$ 481 (Hilton et al., 2008a), and an order of magnitude greater than from the Ganges482 Brahmaputra basin ( $\sim 3$ tonnes $\left.\mathrm{km}^{-2} \mathrm{yr}^{-1}\right)$ (Galy et al., 2007b). However, the real 483 significance lies in the contrasting processes responsible for these fluxes and their 484 geographical scope. In some mountainous settings, high rates of tectonic uplift, often 485 combined with intense cyclonic storms, drive deep-seated landsliding and flooding on 486 a scale and frequency not seen elsewhere. In contrast, runoff-driven hillslope 487 activation observed in the Erlenbach are widely applicable and do not require 488 catastrophic events to initiate significant carbon POC export. Similar processes are 489 likely to occur wherever there is rain on steep, soil-mantled hillslopes that are 490 effectively coupled to stream channels so that there is a direct, unfiltered transfer of 491 material into them. 
493 Meybeck (1993) estimated that $18 \%$ of total atmospheric (i.e. modern) carbon (overall

494 flux of $542 \times 10^{12} \mathrm{~g} \mathrm{yr}^{-1}$ ) is exported as soil-derived POC, or $\sim 98 \times 10^{12} \mathrm{~g} \mathrm{yr}^{-1}$. A

495 direct comparison with the Erlenbach non-fossil POC flux of 14 tonnes $\mathrm{km}^{-2} \mathrm{yr}^{-1}$

496 suggests that $\sim 4.6 \%$ of the world's total land area behaving like the Erlenbach could

497 account for this flux. The global area covered by temperate broadleaf and mixed

498 forests is $\sim 13.5$ million $\mathrm{km}^{2}$ (Mace et al., 2005), or $9 \%$ of the world's land; if other

499 biomes with the potential to host runoff-driven POC export are included (such as

500 temperate coniferous forests and montane grasslands), this rises to $15 \%$. However, it

501 should be noted that steep topography is also an essential ingredient in creating

502 Erlenbach-like conditions. While the biome classification, based on WWF terrestrial

503 ecoregions (Olson et al., 2001), takes account of some factors related to topography,

504 such as climate, it is unlikely to accurately map the topographic limits for the runoff

505 processes described above. Nevertheless, these considerations tentatively suggest that

506 the contribution to global riverine POC flux, particularly the export of non-fossil

507 POC, from Erlenbach-like settings may be more significant than suggested by extant

508 global estimates.

509

510 6. Conclusions

512 We have characterised the processes responsible for transferring organic carbon from

513 hillslope to stream in an alpine headwater catchment with $\mathrm{C}_{\text {org-rich bedrock, a high }}$

514 degree of hillslope-channel coupling and no extreme mass wasting over the timescale

515 of the study. Additionally, we have determined the long-term yields of suspended

516 sediment, total POC, fossil POC and non-fossil POC from this system under moderate

517 conditions. 
519 Suspended sediment exported from the Erlenbach has a mean $\mathrm{C}_{\text {org }}$ of $1.45 \pm 0.06 \%$.

520 Both concentration and composition of this organic carbon vary systematically with

521 hydrological conditions, although variations over any single hydrograph are highly

522 individual. At low discharge, POC concentration and composition is highly variable,

523 due to natural heterogeneity in the small amount of material transported. As

524 discharge increases (along with total suspended load), in-channel clearing causes

525 initial dilution of POC. At a moderate, frequently-crossed threshold $\left(\mathrm{Q} / \mathrm{Q}_{\text {mean }}=10\right)$,

526 the hillslope becomes active and runoff delivers additional POC to the stream in the

527 form of largely soil-derived biomass, causing a bulk shift to higher $\mathrm{C} / \mathrm{N}$ and lower

$528 \delta^{13} \mathrm{C}$ and $\delta^{15} \mathrm{~N}$. This is associated with an increase in the $\mathrm{F}_{\mathrm{nf}}$ from 0.30 during

529 background flow to 0.70 at the highest discharges we have sampled $\left(\mathrm{Q} / \mathrm{Q}_{\text {mean }} \sim 60\right)$.

530 Active precipitation is crucial to the mechanism, with riverine suspended sediment

531 showing greater non-fossil influence and significantly higher $\mathrm{F}_{\mathrm{nf}}$ during rain and on

532 the rising limb than when the rain has stopped and flow is waning. Landslides and

533 channel bank collapse do not regularly contribute to the POC exported under these

534 conditions, but may be activated at extremely high flow rates.

536 Rating curves show power law relationships between discharge and four components:

537 suspended sediment, total POC, fossil POC and non-fossil POC. All exponents are

$538>1$, with fossil POC the lowest at 1.08. Total POC has a significantly higher exponent

539 than suspended sediment, and non-fossil POC has one greater still. Over the past 29

540 years, the conservative estimates of average export fluxes of suspended sediment,

541 total POC, fossil POC and non-fossil POC (in tonnes $\mathrm{km}^{-2} \mathrm{yr}^{-1}$ ) were $1648 \pm 313,23.3$

$542 \pm 5.8,10.1 \pm 1.6$ and $14.0 \pm 4.4$ respectively 
544 We propose that the runoff-driven export of soil-derived POC observed in the

545 Erlenbach is a model for other temperate forested uplands where there is good

546 connectivity between the hillslope and channel. The yield of non-fossil POC from

547 such settings is of the same order of magnitude as those reported from active margin

548 mountain belts, yet the potential area available for this non-catastrophic mode of POC

549 mobilisation extends to large parts of the Earth's continents. Considering our results

550 in the context of previous global estimates of riverine POC discharge, it seems likely

551 that the collective contribution of settings where these processes operate may be more

552 important than previously thought. If the non-fossil POC exported from the

553 Erlenbach and similar catchments is ultimately buried in the ocean, this mechanism

554 could significantly contribute to carbon dioxide drawdown on geological timescales. 


\section{Acknowledgements}

This work was completed as part of a PhD studentship funded by NERC, partly via the British Geological Survey’s British Universities Funding Initiative (BUFI). Radiocarbon analysis was supported by NRCF grant number 1573.0911 . We thank staff at WSL, the Godwin Institute and the Department of Geography, University of Cambridge, for assistance with field- and lab-work. Two anonymous reviewers gave insightful comments that helped to improve the manuscript, and Mike Ellis provided useful feedback on an earlier version. 


\section{References}

Andrews, E. D. (1980). Effective and bankfull discharges of streams in the Yampa

River basin, Colorado and Wyoming. J Hydrol 46, 311-330, doi:10.1016/00221694(80)90084-0

Berner, R. A. (1982). Burial of organic carbon and pyrite sulfur in the modern ocean; its geochemical and environmental significance. Am J Sci 282, 451-473, doi:10.2475/ajs.282.4.451

Blair, N. E., and R. C. Aller (2012). The fate of terrestrial organic carbon in the marine environment. Annu Rev Mar Sci 4, 401-423, doi:10.1146/annurev-marine$120709-142717$

Blair, N. E., E. L. Leithold, S. T. Ford, K. A. Peeler, J. C. Holmes, and D. W. Perkey (2003). The persistence of memory: The fate of ancient sedimentary organic carbon in a modern sedimentary system. Geochim Cosmochim Acta 67, 63-73, doi:10.1016/S0016-7037(02)01043-8

Bouchez, J., O. Beyssac, V. Galy, J. Gaillardet, C. France-Lanord, L. Maurice, and P. Moreira-Turcq (2010). Oxidation of petrogenic organic carbon in the Amazon floodplain as a source of atmospheric $\mathrm{CO}_{2}$. Geology 38, 255-258, doi:10.1130/G30608.1 
Brodie, C. R., J. S. L. Casford, J. M. Lloyd, M. J. Leng, T. H. E. Heaton, C. P. Kendrick, and Z. Yongqiang (2011). Evidence for bias in $\mathrm{C} / \mathrm{N}, \delta^{13} \mathrm{C}$ and $\delta^{15} \mathrm{~N}$ values of bulk organic matter, and on environmental interpretation, from a lake sedimentary sequence by pre-analysis acid treatment methods. Quat Sci Rev 30, 3076-3087, doi:10.1016/j.quascirev.2011.07.003

Carey, A. E., C. B. Gardner, S. T. Goldsmith, W. B. Lyons, and D. M. Hicks (2005). Organic carbon yields from small, mountainous rivers, New Zealand. Geophys Res Lett 31, L15404, doi:10.1029/2005GL023159

Dijkstra, P., A. Ishizu, R. Doucett, S. C. Hart, E. Schwartz, O. V. Menyailo, and B. A. Hungate (2008). $13 \mathrm{C}$ and $15 \mathrm{~N}$ natural abundance of the soil microbial biomass. Soil Biol Biochem 38, 3257-3266, doi:10.1016/j.soilbio.2006.04.005

France-Lanord, C., and L. A. Derry (1994). $\delta^{13} \mathrm{C}$ of organic carbon in the Bengal Fan: Source evolution and transport of $\mathrm{C} 3$ and $\mathrm{C} 4$ plant carbon to marine sediments. Geochim Cosmochim Acta 58, 4809-4814, doi:10.1016/0016-7037(94)90210-0

France-Lanord, C. and L. A. Derry (1997). Organic carbon burial forcing of the carbon cycle from Himalayan erosion. Nature 390, 65-67, doi:10.1038/36324

Galy, V., J. Bouchez, and C. France-Lanord (2007a). Determination of total organic carbon content and $\delta^{13} \mathrm{C}$ in carbonate-rich detrital sediments. Geostand Geoanal Res 31, 199-207, doi:10.1111/j.1751-908X.2007.00864.x 
Galy, V., C. France-Lanord, O. Beyssac, P. Faure, H. Kudrass, and F. Palhol (2007b). Efficient organic carbon burial in the Bengal fan sustained by the Himalayan erosional system. Nature 450, 407-410, doi:10.1038/nature06273

Gomez, B., W. T. Baisden, and K. M. Rogers (2010). Variable composition of particle-bound organic carbon in steepland river systems. J Geophys Res $\mathbf{1 1 5}$, F04006, doi:10.1029/2010JF001713

Gordon, E. S., and M. A. Goñi (2003). Sources and distribution of terrigenous organic matter delivered by the Atchafalaya River to sediments in the northern Gulf of Mexico. Geochim Cosmochim Acta 67, 2359-2375, doi:10.1016/S00167037(02)01412-6

Graz, Y., C. Di-Giovanni, Y. Copard, M. Elie, P. Faure, F. Laggoun Defarge, J. Lévèque, R. Michels, and J. E. Olivier (2011). Occurrence of fossil organic matter in modern environments: Optical, geochemical and isotopic evidence. Appl Geochem 26, 1302-1314, doi:10.1016/j.apgeochem.2011.05.004

Hagedorn, F., P. Schleppi, P. A. Waldner, and H. Flühler (2000). Export of dissolved organic carbon and nitrogen from Gleysol dominated catchments - The significance of water flow paths. Biogeochemistry 50, 137-161, doi:10.1023/A:1006398105953

Hagedorn, F., J. B. Bucher, and P. Schleppi (2001). Contrasting dynamics of dissolved inorganic and organic nitrogen in soil and surface waters of forested 
catchments with Gleysols. Geoderma 100, 173-192, doi:10.1016/S00167061(00)00085-9

Hatten, J. A., M. A. Goñi, and R. A. Wheatcroft (2012). Chemical characteristics of particulate organic matter from a small, mountainous river system in the Oregon Coast Range. Biogeochemistry 107, 43-66, doi:10.1007/s10533-010-9529-z

Hegg, C., B. W. McArdell, and A. Badoux (2006). One hundred years of mountain hydrology in Switzerland by the WSL. Hydrol Process 20, 371-376, doi:10.1002/hyp.6055

Hilton, R. G., A. Galy, and N. Hovius (2008a). Riverine particulate organic carbon from an active mountain belt: Importance of landslides. Glob Biogeochem Cycles 22, GB1017, doi:10.1029/2006GB002905

Hilton, R. G., A. Galy, N. Hovius, M.-C. Chen, M.-J. Horng, and H. Chen (2008b). Tropical-cyclone-driven erosion of the terrestrial biosphere from mountains. Nat Geosci 1, 759-762, doi:10.1038/ngeo333

Hilton, R. G., A. Galy, N. Hovius, M.-J. Horng, and H. Chen (2010). The isotopic composition of particulate organic carbon in mountain rivers of Taiwan. Geochim Cosmochim Acta 74, 3164-3181, doi:10.1016/j.gca.2010.03.004

Hilton, R. G., A. Galy, N. Hovius, S.-J. Kao, M.-J. Horng, and H. Chen (2012). Climatic and geomorphic controls on the erosion of terrestrial biomass from 
subtropical mountain forest. Glob Biogeochem Cycles 26, GB3014, doi:10.1029/2012GB004314

Horton, R. E. (1945). Erosional development of streams and their drainage basins; hydrophysical approach to quantitative morphology. Geol Soc Am Bull 56, 275-370, doi:10.1130/0016-7606(1945)56[275:EDOSAT]2.0.CO;2

Kao, S.-J., and K.-K. Liu (1996). Particulate organic carbon export from a subtropical mountainous river (Lanyang Hsi) in Taiwan. Limnol Oceanogr 41, 1749-1757

Komada, T., E. R. M. Druffel, and S. E. Trumbore (2004). Oceanic export of relict carbon by small mountainous rivers. Geophys Res Lett 31, L07504, doi:10.1029/2004GL019512

Komada, T., E. R. M. Druffel, and J. Hwang (2005). Sedimentary rocks as sources of ancient organic carbon to the ocean: An investigation through $\Delta^{14} \mathrm{C}$ and $\delta^{13} \mathrm{C}$ signatures of organic compound classes. Glob Biogeochem Cycles 19, GB2017, doi:10.1029/2004GB002347

Leithold, E. L., N. E Blair, and D. W. Perkey (2006). Geomorphologic controls on the age of particulate organic carbon from small mountainous and upland rivers. Glob Biogeochem Cycles 20, GB3022, doi:10.1029/2005GB002677 
Lyons, W. B., C. A. Nezat, A. E. Carey, and D. M. Hicks (2002). Organic carbon fluxes to the ocean from high-standing islands. Geology 30, 443-446, doi:10.1130/0091-7613(2002)030<0443:OCFTTO >2.0.CO;2

Mace, G., H. Masundire, and J. Baillie (2005). Biodiversity, in Ecosystems and Human Well-being: Current State and Trends, Volume 1 (Millennium Ecosystem Assessment Report), edited by Hassan, R., R. Scholes, and N. Ash, pp. 77-122, Island Press, USA

Masiello, C. A., and E. R. M. Druffel (2001). Carbon isotope geochemistry of the Santa Clara River. Glob Biogeochem Cycles 15, 407-416, doi:10.1029/2000GB001290

Meybeck, M. (1993). Riverine transport of atmospheric carbon: Sources, global typology and budget. Water Air Soil Poll 70, 443-463, doi:10.1007/BF01105015

Milliman, J. D., and J. P. M. Syvitski (1992). Geomorphic/tectonic control of sediment discharge to the ocean: the importance of small mountainous rivers. J Geol $100,525-544$

Nash, D. B. (1994). Effective sediment-transporting discharge from magnitudefrequency analysis. J Geol 102, 79-95

Olson, D. M, E. Dinerstein, E. D. Wikramanayake, N. D. Burgess, G. V. N. Powell, E. C. Underwood, J. A. D’amico, I. Itoua, H. E. Strand, J. C. Morrison, C. J. Loucks, 
T. F. Allnutt, T. H. Ricketts, Y. Kura, J. F. Lamoreux, W. W. Wettengel, P. Hedao, and K. R. Kassem (2001). Terrestrial ecoregions of the world: a new map of life on Earth. BioScience 51, 933-938, doi:10.1641/00063568(2001)051[0933:TEOTWA]2.0.CO;2

Prahl, F. G., J. R Ertel, M. A. Goñi, M. A. Sparrow, and B. Eversmeyer (1994). Terrestrial organic carbon contributions to sediments on the Washington margin. Geochim Cosmochim Acta 58, 3035-3048, doi:10.1016/0016-7037(94)90177-5

Rickenmann, D. and B. McArdell (2007). Continuous measurement of sediment transport in the Erlenbach stream using piezoelectric bedload impact sensors. Earth Surf Proc Land 32, 1362-1378, doi:10.1002/esp.1478

Rickenmann, D., J. M. Turowski, B. Fritschi, A. Klaiber, and A. Ludwig (2012). Bedload transport measurements at the Erlenbach stream with geophones and automated basket samplers. Earth Surf Proc Land 37, 1000-1011, doi:10.1002/esp.3225

Schleppi, P., N. Muller, H. Feyen, A. Papritz, J. B. Bucher, and H. Flühler (1998). Nitrogen budgets of two small experimental forested catchments at Alptal, Switzerland. Forest Ecol Manag 101, 177-185, doi:10.1016/S0378-1127(97)00134-5

Schleppi, P., N. Muller, P. J. Edwards, and J. B. Bucher (1999). Three years of increased nitrogen deposition do not affect the vegetation of a montane forest ecosystem. Phyton 39, 197-204 
Schleppi, P., Hagedorn, F., and I. Providoli (2004). Nitrate leaching from a mountain forest ecosystem with gleysols subjected to experimentally increased $\mathrm{N}$ deposition. Water, Air and Soil Pollution: Focus 4, 453-467, doi:10.1023/B:WAFO.0000028371.72044.fb

Schleppi, P., P. A. Waldner, and B. Fritschi (2006). Accuracy and precision of different sampling strategies and flux integration methods for runoff water: Comparisons based on measurements of the electrical conductivity. Hydrol Proc 20, 395-410, doi:10.1002/hyp.6057

Schuerch, P., A. L. Densmore, B. W. McArdell, and P. Molnar (2006). The influence of landsliding on sediment supply and channel change in a steep mountain catchment. Geomorphology 78, 222-235, doi:10.1016/j.geomorph.2006.01.025

Turowski, J. M, E. M. Yager, A. Badoux, D. Rickenmann, and P. Molnar (2009). The impact of exceptional events on erosion, bedload transport and channel stability in a step-pool channel. Earth Surf Proc Land 34, 1661-1673, doi:10.1002/esp.1855

Turowski, J.M., D. Rickenmann and S.J. Dadson (2010). The partitioning of the total sediment load of a river into suspended load and bedload: a review of empirical data. Sedimentology 57, 1126-1146, doi:10.1111/j.1365-3091.2009.01140.x 
Turowski, J. M., A. Badoux, and D. Rickenmann (2011). Start and end of bedload transport in gravel-bed streams. Geophs Res Lett 38, L04401, doi:10.1029/2010GL046558

West, A. J., C.-W. Lin, T.-C. Lin, R. G. Hilton, S.-H. Liu, C.-T. Chang, K.-C. Lin, A. Galy, R. B. Sparkes, and N. Hovius (2011). Mobilization and transport of coarse woody debris to the oceans triggered by an extreme tropical storm. Limnol Oceanogr 56, 77-85, doi:10.4319/lo.2011.56.1.0077

Wheatcroft, R. A., M. A. Goñi, J. A. Hatten, G. B. Pasternack, and J. A. Warrick (2010). The role of effective discharge in the ocean delivery of particulate organic carbon by small, mountainous river systems. Limnol Oceanogr 55, 161-171, doi:10.4319/1o.2010.55.1.0161

Winkler, W., W. Wildi, J. van Stuijvenberg, and C. Caron (1985). Wägital-Flysch et autres flyschs penniques en Suisse Centrale: Stratigraphie, sédimentologie et comparaisons. Eclogae Geol Helv 78, 1-22

Wright, R. F., and L. Rasmussen (1998). Introduction to the NITREX and EXMAN projects. Forest Ecol Manag 101, 1-7, doi:10.1016/S0378-1127(97)00120-5 


\section{Figure Captions}

Figure 1. Hydrographs for 3 of the 5 storm events sampled in July 2010. Dark grey area is precipitation $(\mathrm{x} 100$, in $\mathrm{mm})$; light grey area is discharge $\left(\mathrm{Q}\right.$, in $\left.1 \mathrm{~s}^{-1}\right)$.

Suspended sediment concentration (SSC, x 100, in $\mathrm{g}^{-1}$ ), organic carbon concentration $\left(\mathrm{C}_{\mathrm{org}}\right.$, in \%), carbon isotopic composition $\left(\delta^{13} \mathrm{C}\right.$ in \%o), and organic carbon to nitrogen ratio $(\mathrm{C} / \mathrm{N})$ are represented by circles, squares, triangles, and diamonds, respectively. Final panel shows the average annual hydrograph over the 29 -year monitoring period (1983-2011), and mean suspended sediment concentrations of samples collected every 1-2 weeks over a 6-year period (2005-2010) (SSC data from the Swiss National River Monitoring and Survey Programme, http://www.eawag.ch/forschung/wut/schwerpunkte/chemievonwasserresourcen/naduf/ datendownload_EN).

Figure 2. Variation of organic carbon concentration in riverine suspended sediment with total suspended load (note logarithmic $x$-axis). Open symbols are background flow $\left(\mathrm{Q} / \mathrm{Q}_{\text {mean }}<10\right)$. POC $=$ particulate organic carbon.

Figure 3. Top: nitrogen to carbon ratios $(\mathrm{N} / \mathrm{C})$ and carbon isotopic composition $\left(\delta^{13} \mathrm{C}\right)$ of Erlenbach riverine suspended sediment, hillslope runoff suspended sediment and major stores of carbon within the catchment. Bottom: carbon to nitrogen ratios $(\mathrm{C} / \mathrm{N})$ and nitrogen isotopic composition $\left(\delta^{15} \mathrm{~N}\right)$ of the same pools.

Figure 4. Zoomed-in views of the plots in Figure 3, where suspended sediment samples are colour-coded according to total suspended load (warm colours represent 
low values; cold colours represent high values). Open squares are background flow $\left(\mathrm{Q} / \mathrm{Q}_{\text {mean }}<10\right)$. 'Fossil end member' includes bedrock, bedload, channel banks and landslides. Dotted lines indicate potential mixing zones between the fossil end member and non-fossil sources. Determination and nature of the hypothetical nonfossil end member is discussed section 5.1.

Figure 5. Rating curves showing power law relationships between $\mathrm{Q} / \mathrm{Q}_{\text {mean }}$ and suspended sediment concentration, total POC (tPOC), fossil POC (fPOC) and nonfossil POC (nfPOC), all in $\mathrm{mg}^{-1}$. POC is particulate organic carbon concentration. Small squares represent individual samples; open symbols are background flow $\left(\mathrm{Q} / \mathrm{Q}_{\text {mean }}<10\right)$. Dashed lines are $95 \%$ confidence bands. 
Table 1. Characteristics of the five storm events sampled.

\begin{tabular}{lllll}
\hline Date & Approx. time (UTC+2) & Number of samples $^{\mathrm{a}}$ & Peak Q $\left.\mathbf{( l ~ s}^{-\mathbf{1}}\right)$ & ${\text { Peak } \mathbf{Q} / \mathbf{Q}_{\text {mean }}}^{\mathbf{b}}$ \\
\hline 12 July 2010 & $19.00-20.30$ & 37 & 2290 & 59 \\
22-23 July 2010 & $20.30-02.30$ & $37+1$ preceding & 420 & 11 \\
26 July 2010 & $21.00-00.00$ & $16+1$ preceding & 300 & 8 \\
29 July 2010 & $06.30-16.45$ & 25 & 1190 & 31 \\
30 July 2010 & $08.45-16.00$ & 9 & 1580 & 41 \\
\hline
\end{tabular}

${ }^{a}$ Additional samples for 22 and 26 July were collected at intervening low flow. ${ }^{\mathrm{b}} \mathrm{Q} / \mathrm{Q}_{\text {mean }}$ is the discharge relative to the average discharge over the period 1983-2011 inclusive $\left(38.61 \mathrm{~s}^{-1}\right)$. 
Table 2. Organic carbon concentration $\left(\mathrm{C}_{\mathrm{org}}\right)$, carbon to nitrogen ratio $(\mathrm{C} / \mathrm{N})$, carbon isotopic composition $\left(\delta^{13} \mathrm{C}\right)$ and nitrogen isotopic composition $\left(\delta^{15} \mathrm{~N}\right)$ of major carbon stores within the catchment, and hillslope runoff and riverine suspended sediment ${ }^{\mathrm{a}}$.

\begin{tabular}{|c|c|c|c|c|c|c|c|c|c|}
\hline & \multirow{2}{*}{$n$} & \multicolumn{2}{|c|}{$\mathrm{C}_{\text {org }}(\%)$} & \multicolumn{2}{|c|}{$\mathrm{C} / \mathrm{N}$} & \multicolumn{2}{|c|}{$\delta^{13} \mathrm{C}(\%)$} & \multicolumn{2}{|c|}{$\delta^{15} \mathrm{~N}(\%)$} \\
\hline & & Mean & $\sigma$ & Mean & $\sigma$ & Mean & $\sigma$ & Mean & $\sigma$ \\
\hline Bedrock & 22 & $0.54 \pm 0.11$ & 0.26 & $7.81 \pm 1.7$ & 3.98 & $-25.71 \pm 0.36$ & 0.84 & $3.34 \pm 0.26$ & 0.60 \\
\hline Bedload & 11 & $0.87 \pm 0.21$ & 0.36 & $9.78 \pm 0.9$ & 1.57 & $-25.84 \pm 0.10$ & 0.17 & $2.13 \pm 0.23$ & 0.38 \\
\hline Channel banks & 8 & $0.87 \pm 0.22$ & 0.32 & $8.12 \pm 1.1$ & 1.58 & $-25.89 \pm 0.40$ & 0.57 & $2.91 \pm 0.29$ & 0.40 \\
\hline Landslide profile & 22 & $0.64 \pm 0.06$ & 0.15 & $7.38 \pm 0.4$ & 0.87 & $-26.03 \pm 0.12$ & 0.28 & $2.67 \pm 0.30$ & 0.71 \\
\hline Deep soil ${ }^{\mathrm{p}}$ & 10 & $2.15 \pm 1.2$ & 1.85 & $11.8 \pm 2.3$ & 3.64 & $-25.98 \pm 0.34$ & 0.54 & $3.56 \pm 1.99$ & 3.14 \\
\hline Surface soil ${ }^{\mathrm{b}}$ & 17 & $16.5 \pm 6.3$ & 12.9 & $17.9 \pm 2.2$ & 4.45 & $-26.84 \pm 0.48$ & 0.98 & $-1.33 \pm 0.77$ & 1.59 \\
\hline Foliage & 8 & $46.9 \pm 2.0$ & 2.88 & $55.5 \pm 17$ & 24.2 & $-28.30 \pm 1.13$ & 1.60 & $-5.87 \pm 1.67$ & 2.36 \\
\hline Woody debris & 12 & $49.1 \pm 1.8$ & 3.18 & $173 \pm 98$ & 170 & $-25.25 \pm 0.69$ & 1.19 & $-3.99 \pm 1.29$ & 2.24 \\
\hline $\begin{array}{l}\text { Hypothetical non-fossil end } \\
\text { member }\end{array}$ & - & - & - & $15.8 \pm 6.8$ & - & $-27.15 \pm 0.53$ & - & $0.61 \pm 1.40$ & - \\
\hline Forest hillslope runoff & 38 & $9.12 \pm 0.9$ & 2.77 & $12.6 \pm 0.7$ & 2.28 & $-26.50 \pm 0.08$ & 0.23 & $2.48 \pm 0.30$ & 0.93 \\
\hline Meadow hillslope runoff & 10 & $15.9 \pm 1.7$ & 2.67 & $12.6 \pm 1.8$ & 2.91 & $-26.56 \pm 0.50$ & 0.79 & $4.43 \pm 1.04$ & 1.64 \\
\hline Riverine suspended sediment $^{\mathrm{c}}$ & 122 & $1.45 \pm 0.06$ & 0.32 & $9.55 \pm 0.2$ & 1.34 & $-26.33 \pm 0.08$ & 0.45 & $2.21 \pm 0.16$ & 0.87 \\
\hline Rising limb & 72 & $1.36 \pm 0.07$ & 0.29 & $9.89 \pm 0.3$ & 1.35 & $-26.45 \pm 0.08$ & 0.32 & $1.95 \pm 0.13$ & 0.56 \\
\hline Falling limb & 50 & $1.57 \pm 0.09$ & 0.33 & $9.16 \pm 0.4$ & 1.29 & $-26.16 \pm 0.15$ & 0.54 & $2.58 \pm 0.31$ & 1.09 \\
\hline Raining & 85 & $1.40 \pm 0.06$ & 0.29 & $10.0 \pm 0.3$ & 1.32 & $-26.49 \pm 0.07$ & 0.34 & $1.94 \pm 0.12$ & 0.53 \\
\hline Dry & 37 & $1.55 \pm 0.12$ & 0.37 & $8.69 \pm 0.4$ & 1.07 & $-25.98 \pm 0.15$ & 0.47 & $2.83 \pm 0.38$ & 1.15 \\
\hline
\end{tabular}

deviation; errors are \pm twice the standard error on the mean.

${ }^{\mathrm{b}}$ Surface soil samples were collected from the top $\sim 10 \mathrm{~cm}$ (without overlying vegetation); deep soil samples were collected from below $10 \mathrm{~cm}$ in two vertical profiles.

${ }^{\mathrm{c}}$ Riverine suspended sediment is subdivided into samples collected during i) rising and falling limbs and ii) active rainfall and dry periods. 
Table 3. Results of radiocarbon analysis on selected samples ${ }^{\mathrm{a}}$.

\begin{tabular}{|c|c|c|c|c|c|c|c|}
\hline \multicolumn{2}{|c|}{ Sample Type } & \multirow{2}{*}{ Sample ID } & \multirow{2}{*}{$\begin{array}{l}\text { Publication } \\
\text { code }\end{array}$} & \multirow{2}{*}{$\begin{array}{l}\mathrm{C}_{\text {org }} \\
(\%)\end{array}$} & \multirow{2}{*}{$\begin{array}{l}F_{\text {mod }} \\
(\text { fraction of } \\
\text { modern } C)^{b}\end{array}$} & \multirow{2}{*}{$\Delta^{14} \mathrm{C}(\% \circ)$} & \multirow{2}{*}{$\begin{array}{l}\text { Conventional } \\
\text { radiocarbon } \\
\text { age (years BP) }\end{array}$} \\
\hline \multirow{4}{*}{$\begin{array}{l}\text { Suspended } \\
\text { sediment }\end{array}$} & $Q\left(1 s^{-1}\right)$ & & & & & & \\
\hline & 78 & 12.71748 & SUERC-40494 & 2.2 & $0.68 \pm 0.004$ & $-317.9 \pm 3.5$ & $3073 \pm 41$ \\
\hline & 517 & 29.71768 & SUERC-39232 & 1.3 & $0.47 \pm 0.002$ & $-530.5 \pm 2.3$ & $6074 \pm 39$ \\
\hline & 1170 & 12.71711 & SUERC-39229 & 2.2 & $0.74 \pm 0.004$ & $-256.5 \pm 3.5$ & $2381 \pm 38$ \\
\hline \multirow{4}{*}{\multicolumn{2}{|c|}{ Surface soil }} & ER-ST-1-L-0 & SUERC-39216 & 1.2 & $0.53 \pm 0.003$ & $-471.7 \pm 2.6$ & $5123 \pm 39$ \\
\hline & & ER-ST-2-L-15 & SUERC-39219 & 6.0 & $1.00 \pm 0.005$ & $-3.5 \pm 4.7$ & Modern \\
\hline & & ER-ST-1-R-350 & SUERC-39220 & 25 & $1.06 \pm 0.005$ & $64.8 \pm 5.0$ & Modern \\
\hline & & ER-ST-1-R-20 & SUERC-39221 & 11 & $1.05 \pm 0.005$ & $53.9 \pm 5.0$ & Modern \\
\hline \multicolumn{2}{|c|}{ Wood entrained in bedload } & ER-V-19 & SUERC-39222 & 50 & $0.81 \pm 0.004$ & $-186.5 \pm 3.8$ & $1658 \pm 37$ \\
\hline
\end{tabular}

${ }^{\mathrm{a}}$ Errors are $\pm 1 \sigma$.

${ }^{b}$ Reference date for $\mathrm{F}_{\text {mod }}$ is 1950 ; therefore $\mathrm{F}_{\text {mod }}$ can be $>1$ in plants and soils due to incorporation of ${ }^{14} \mathrm{C}$ from nuclear weapons testing during the second half of the twentieth century. 
Table 4. Rating curve parameters for power law relationships between $\mathrm{Q} / \mathrm{Q}_{\text {mean }}$ and suspended sediment (SS) or particulate organic carbon (POC), of the form SS or POC $=a\left(\mathrm{Q} / \mathrm{Q}_{\text {mean }}\right)^{b(\mathrm{a})}$.

\begin{tabular}{|c|c|c|c|c|c|}
\hline & $a$ & $\boldsymbol{b}$ & $\mathbf{R}^{2(\mathbf{b})}$ & $Q_{e}\left(1 s^{-1}\right)^{c}$ & $\begin{array}{l}\mathbf{Q}_{\mathrm{e}} \\
\left(\mathbf{Q} / \mathbf{Q}_{\text {mean }}\right)^{\mathrm{c}}\end{array}$ \\
\hline SS & $\begin{array}{l}99.7 \pm 29.4 \\
96.0 \pm 44.2\end{array}$ & $\begin{array}{l}1.19 \pm 0.08 \\
1.20 \pm 0.12\end{array}$ & $\begin{array}{l}0.78 \\
0.68\end{array}$ & 300 & 7.7 \\
\hline tPOC & $\begin{array}{l}0.96 \pm 0.30 \\
0.96 \pm 0.48\end{array}$ & $\begin{array}{l}1.33 \pm 0.08 \\
1.33 \pm 0.13\end{array}$ & $\begin{array}{l}0.81 \\
0.71 \\
\end{array}$ & 400 & 10.4 \\
\hline fPOC & $\begin{array}{l}0.80 \pm 0.39 \\
0.75 \pm 0.64\end{array}$ & $\begin{array}{l}1.08 \pm 0.13 \\
1.10 \pm 0.23\end{array}$ & $\begin{array}{l}0.50 \\
0.32\end{array}$ & 230 & 5.6 \\
\hline nfPOC & $\begin{array}{l}0.41 \pm 0.20 \\
0.44 \pm 0.33\end{array}$ & $\begin{array}{l}1.45 \pm 0.13 \\
1.43 \pm 0.20\end{array}$ & $\begin{array}{l}0.70 \\
0.57\end{array}$ & 520 & 13.4 \\
\hline
\end{tabular}

${ }^{\mathrm{a}}$ Values in regular type (used for flux calculations) are based on the whole sample set; values in italics are based only on samples with $\mathrm{Q} / \mathrm{Q}_{\text {mean }}>10$. There are three classes of POC: total (tPOC), fossil (fPOC) and non-fossil (nfPOC).

${ }^{\mathrm{b}}$ Correlation coefficients are given as $\mathrm{R}^{2}$.

${ }^{\mathrm{c}} \mathrm{Q}_{\mathrm{e}}$ is the effective discharge, as defined by Wheatcroft et al. (2010). Q/ $\mathrm{Q}_{\text {mean }}$ is the discharge relative to the average discharge over the period 1983-2011 inclusive (38.61 $\left.\mathrm{s}^{-1}\right)$.

Table 5. Modeled export of suspended sediment (SS) and total, fossil and non-fossil particulate organic carbon (tPOC, fPOC and nfPOC), averaged over 29 years (19832011 inclusive).

\begin{tabular}{|c|c|c|c|c|c|c|}
\hline & \multirow{2}{*}{$\begin{array}{l}\text { Mean } \\
\text { annual } \\
\text { yield } \\
\text { (tonnes) }\end{array}$} & \multicolumn{4}{|c|}{$\begin{array}{l}\text { Mean annual yield (tonnes) according to } Q / Q_{\text {mean }}\left(\mathrm{l} \mathrm{s}^{-1}\right) \text {. Proportions in each } \\
\text { class are given in brackets. }\end{array}$} & \multirow{2}{*}{$\begin{array}{l}\text { Export } \\
\text { flux }(t \\
\left.\mathbf{k m}^{-2} \mathbf{y r}^{-1}\right)\end{array}$} \\
\hline & & $\begin{array}{l}Q / Q_{\text {mean }} \leq 1 \\
(77 \%)\end{array}$ & $\begin{array}{l}1<Q / Q_{\text {mean }} \leq 10 \\
(22 \%)\end{array}$ & $\begin{array}{l}10<Q / Q_{\text {mean }} \leq 60 \\
(1 \%)\end{array}$ & $\begin{array}{l}\mathrm{Q} / \mathbf{Q}_{\text {mean }}>60^{\mathrm{b}} \\
(<0.01 \%)\end{array}$ & \\
\hline SS & $\begin{array}{l}1220 \pm \\
232\end{array}$ & $\begin{array}{l}12.0 \pm 0.79 \\
(1.1 \%)\end{array}$ & $\begin{array}{l}376 \pm 35.3 \\
(32 \%)\end{array}$ & $\begin{array}{l}740 \pm 91.8 \\
(61 \%)\end{array}$ & $\begin{array}{l}91.1 \pm 61.3(5.8 \%) \\
215 \pm 171(10 \%)\end{array}$ & $\begin{array}{l}1648 \pm \\
313\end{array}$ \\
\hline tPOC & $17.3 \pm 4.3$ & $\begin{array}{l}0.11 \pm 0.01 \\
(0.7 \%)\end{array}$ & $\begin{array}{l}4.57 \pm 0.44 \\
(28 \%)\end{array}$ & $\begin{array}{l}11.0 \pm 1.40 \\
(64 \%)\end{array}$ & $\begin{array}{l}1.57 \pm 1.06(6.9 \%) \\
4.21 \pm 3.43(12 \%)\end{array}$ & $23.3 \pm 5.8$ \\
\hline fPOC & $7.44 \pm 1.2$ & $\begin{array}{l}0.10 \pm 0.01 \\
(1.5 \%)\end{array}$ & $\begin{array}{l}2.56 \pm 0.24 \\
(36 \%)\end{array}$ & $\begin{array}{l}4.30 \pm 0.53 \\
(58 \%)\end{array}$ & $\begin{array}{l}0.47 \pm 0.32(5.1 \%) \\
1.02 \pm 0.79(8.6 \%)\end{array}$ & $10.1 \pm 1.6$ \\
\hline nfPOC & $10.4 \pm 3.2$ & $\begin{array}{l}0.04 \pm 0.00 \\
(0.5 \%)\end{array}$ & $\begin{array}{l}2.39 \pm 0.23 \\
(26 \%)\end{array}$ & $\begin{array}{l}6.85 \pm 0.88 \\
(67 \%)\end{array}$ & $\begin{array}{l}1.10 \pm 0.74(7.3 \%) \\
3.29 \pm 2.73(13 \%)\end{array}$ & $14.0 \pm 4.4$ \\
\hline$F_{n f}{ }^{a}$ & $\begin{array}{l}0.61 \pm \\
0.02 \\
\end{array}$ & $0.30 \pm 0.00$ & $0.48 \pm 0.00$ & $0.61 \pm 0.00$ & $\begin{array}{l}0.70 \pm 0.00 \\
0.76 \pm 0.02\end{array}$ & - \\
\hline
\end{tabular}

${ }^{\mathrm{a}} \mathrm{F}_{\mathrm{nf}}$ is the modeled fraction of organic carbon derived from non-fossil sources, given overall in the first column and then for separate discharge classes.

${ }^{\mathrm{b}}$ For $\mathrm{Q} / \mathrm{Q}_{\text {mean }}>60$, the top line (normal type; used in calculating overall yields and fluxes) assumes that the rating curves are flat from $\mathrm{Q} / \mathrm{Q}_{\text {mean }}=60$; the bottom line (italics; given for comparison only) assumes that the same rating relationships apply above this limit. 

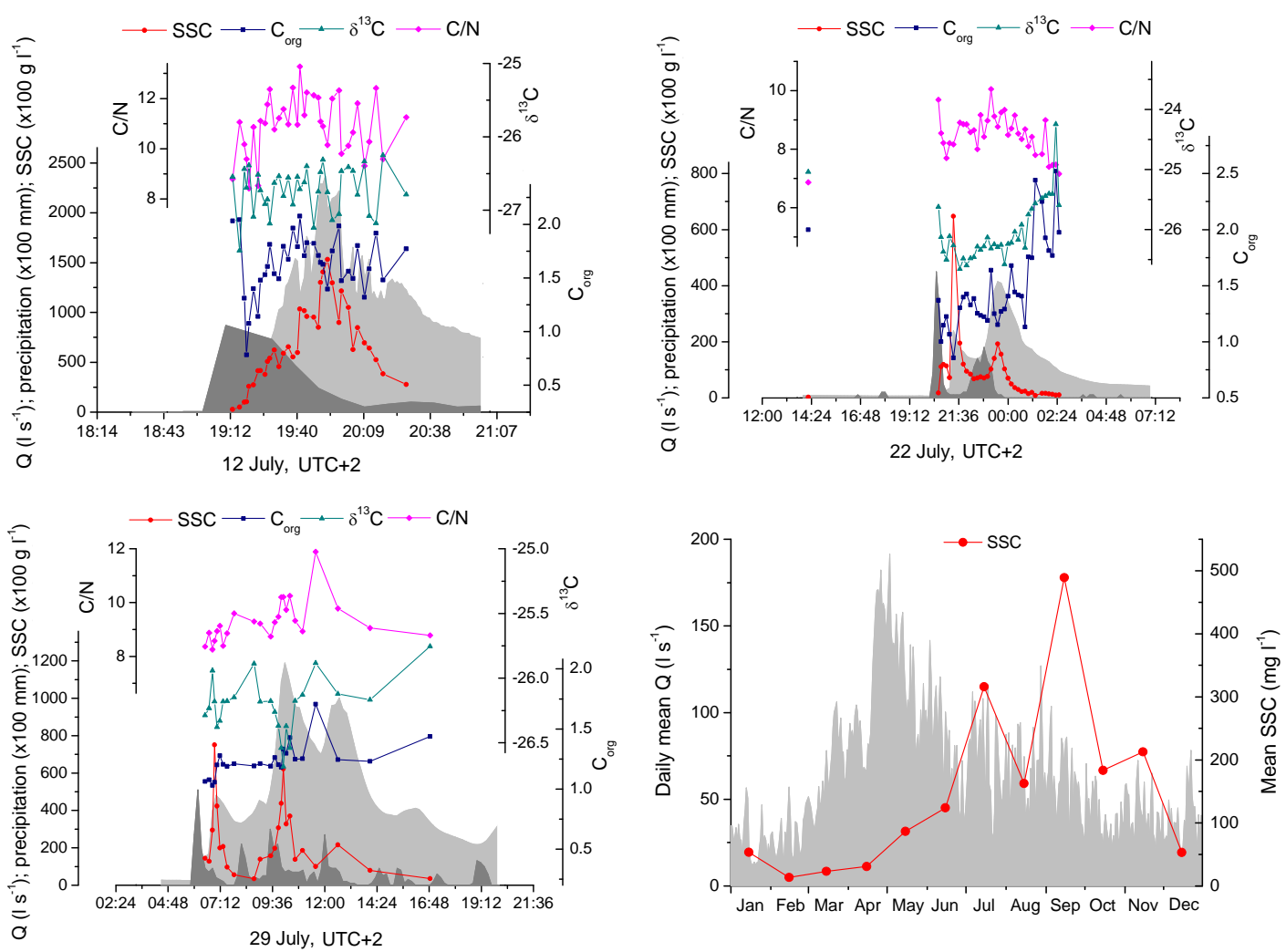

Figure 1

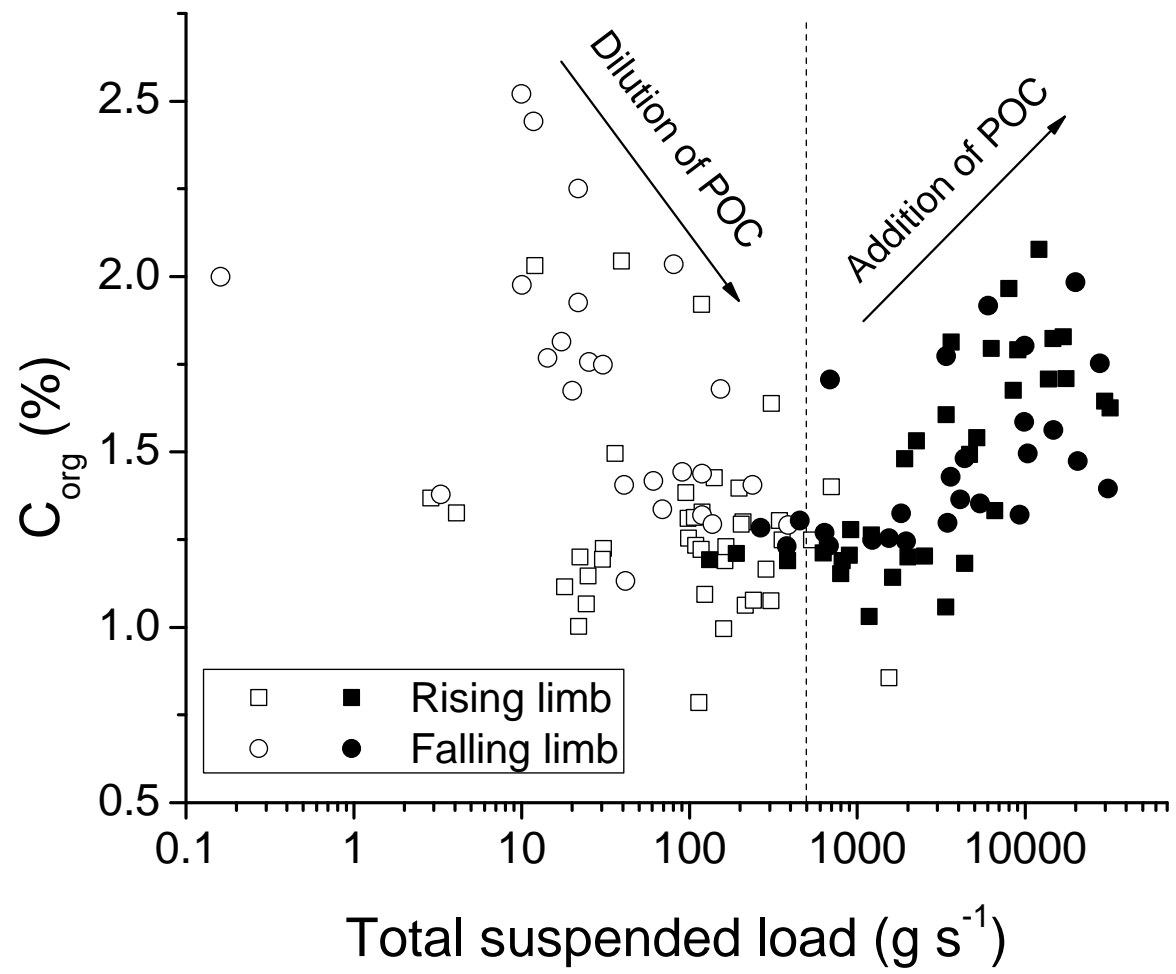

Figure 2 

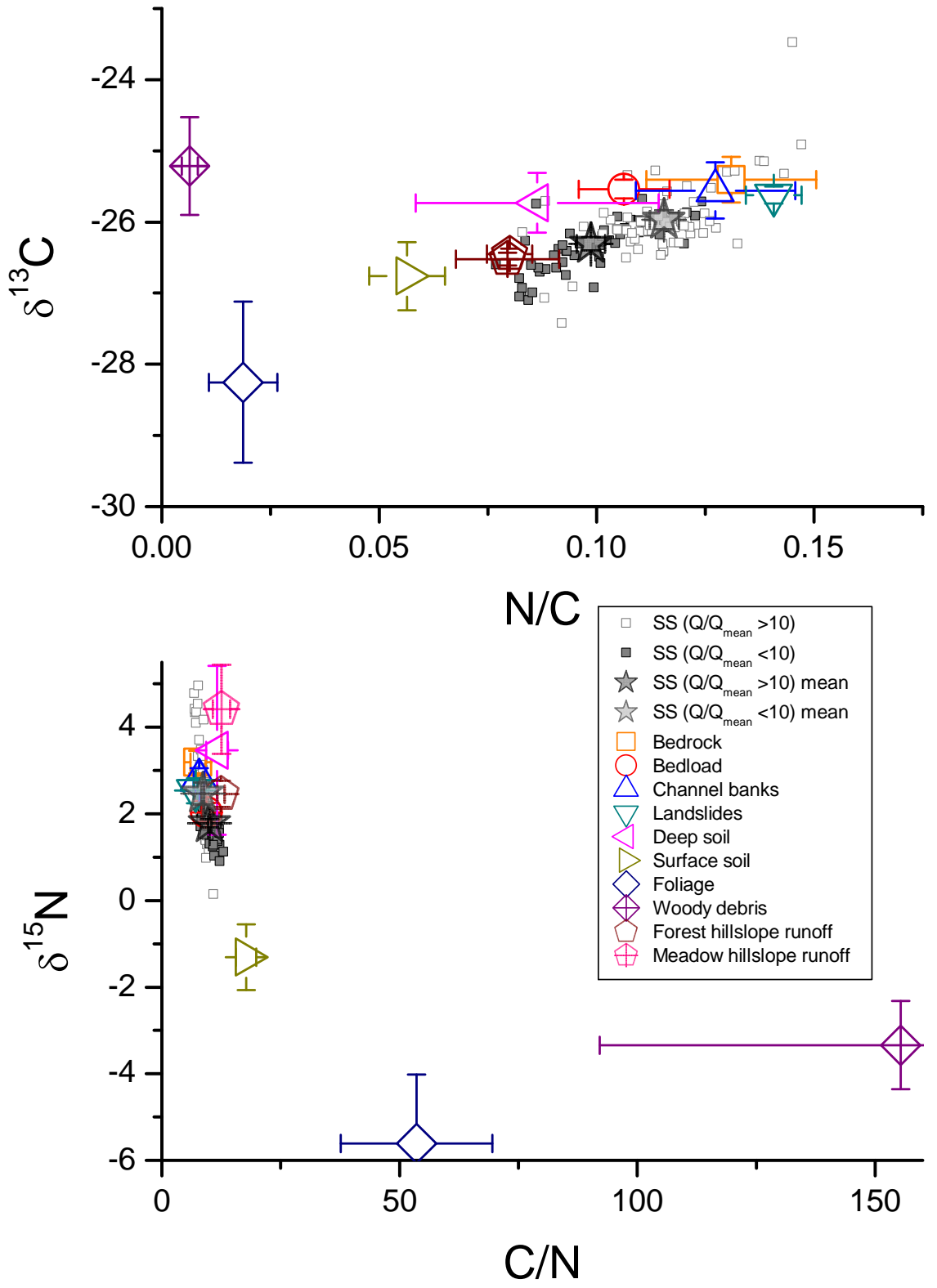

Figure 3 

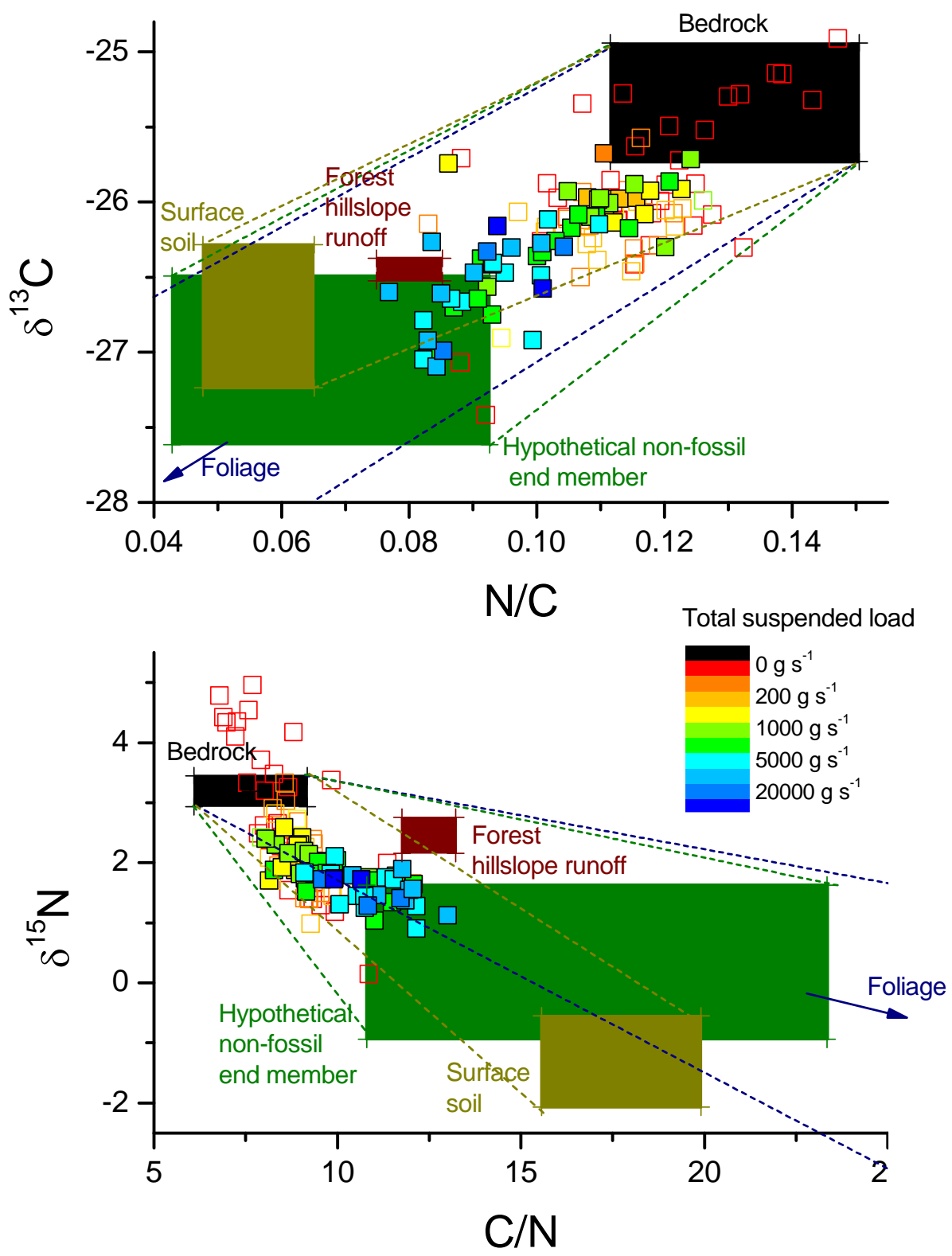

Figure 4 

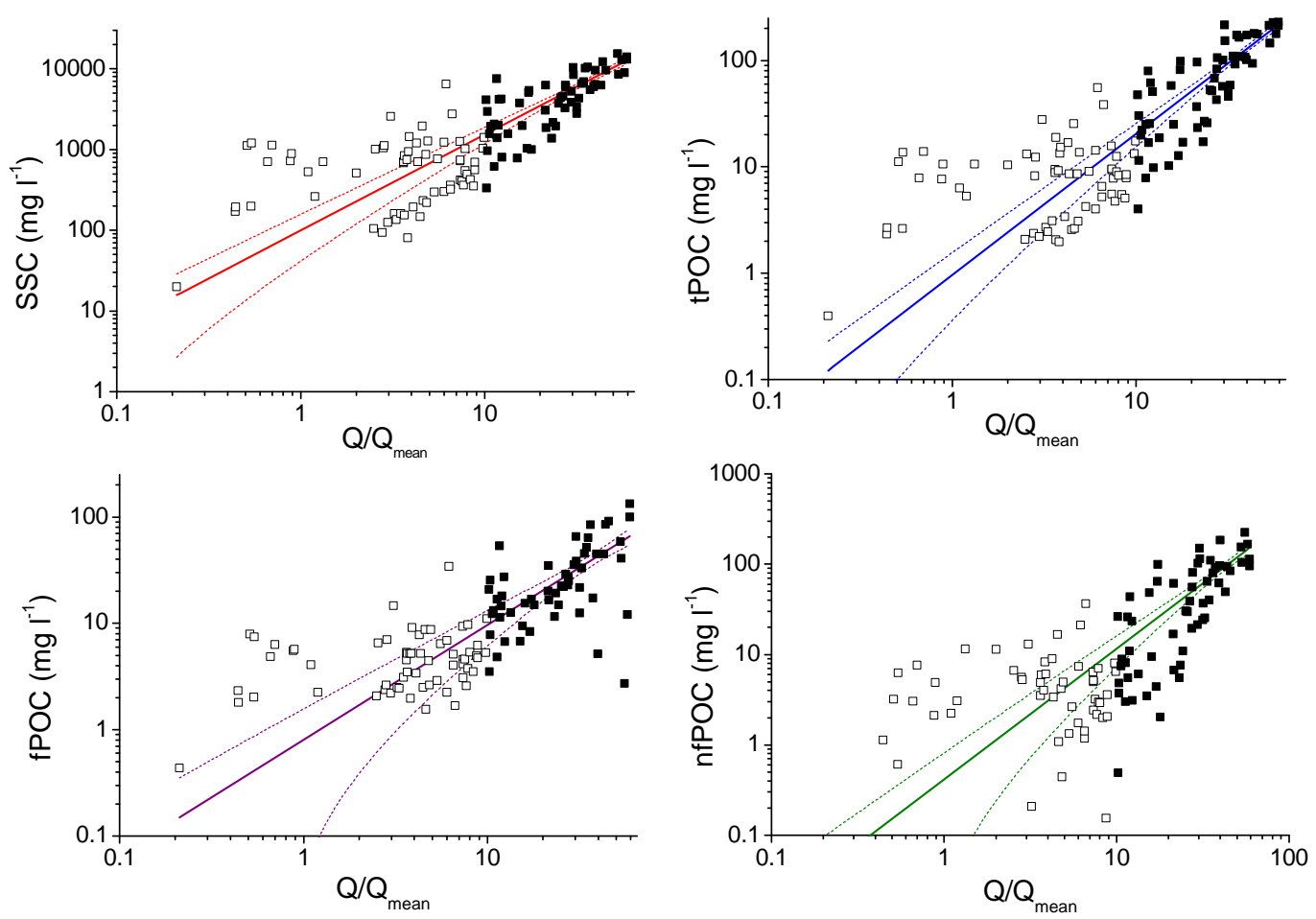

Figure 5 